\title{
Growth of Soybean Plant (Glycine Max) in Soya Waste Blended Soil
}

\author{
P. B. THAKARE ${ }^{a^{*}}$, M. D. CHAUDHARY ${ }^{\mathrm{b}}$ and W. K. POKALE ${ }^{\mathrm{c}}$ \\ ${ }^{a}$ Arts, Commerce and Science college, Arvi, Dist. Wardha, M.S., India \\ ${ }^{\mathrm{b}}$ B. D. College of Engineering, Sevagram, Dist. Wardha, M.S., India \\ ${ }^{\mathrm{c}}$ Principal, Sri. Saraswati Social work College, Wasim, M.S., India \\ thakare.pawan@gmail.com
}

Received 29 November 2012 / Accepted 18 December 2012

\begin{abstract}
Physicochemical characterization of soya waste an effluent of soybean oil industry and three different soils was carried out. The growth of soybean plant was studied in 0, 2, 5, 10, 15, 20 and 30\% etc. blended soil with soya waste. Growth of plants was monitored regularly after every month up to three months from the date of plantation for all the three soils in rainy, winter and summer seasons of the year 2009-10. From the commercial view point, overall maximum number of fruits was found in rainy season for $10-30 \%$ blending, in winter for $5-10 \%$ blending and in summer for $10 \%$ blending. The results of the present work shows the possibility of use of effluents by blending with soil for better plant growth.
\end{abstract}

Keywords: Blended soil, Industrial effluent, Plant growth, Soybean

\section{Introduction}

Soil mainly consists of mixtures of organic and inorganic matters and water. The essential micronutrients required for plant growth are $\mathrm{C}, \mathrm{H}, \mathrm{O}, \mathrm{N}, \mathrm{P}, \mathrm{S}, \mathrm{K}, \mathrm{Ca}, \mathrm{Mg}, \mathrm{Fe}$ etc. $\mathrm{N}, \mathrm{P}$ and $\mathrm{K}$ are usually supplied in the form of manure and fertilizers to the soil.

Rapid industrialization, population explosion and more urbanization in India have created enormous problems of environmental pollution in terms of generating the variable quality and quantity of solid and liquid waste. In developing countries, there has not been much emphasis on the installation of sewage treatment plants and all the industrial effluents are generally discharged into the sewage system.

Intensive contamination of soil by sewage and industrial effluents has affected adversely both soil health and crop productivity. Sewage and industrial effluents are rich sources both beneficial as well as harmful elements. Since some of these effluents are rich sources of plant nutrients therefore soil provides the logical sink for these disposals. But many untreated and contaminated sewage and industrial effluents may have high concentration of several heavy metals ${ }^{1,2}$ such as $\mathrm{Cd}, \mathrm{Ni}, \mathrm{Pb}$ and $\mathrm{Cr}$. 
It has been found by many workers that continuous disposal of industrial effluents on agricultural soils has resulted in soil sickness and also accumulation of some of the toxic metals in soil has been reported ${ }^{3-7}$ which may pose serious human and animal health. In Punjab, groundwater has been contaminated by $\mathrm{Hg}$ and $\mathrm{Pb}$ to such an extent that it is causing mutation of DNA of the people, who drink it ${ }^{8}$. Soil ecosystem has been contaminated throughout the world by various anthropogenic activities resulting in health hazards through food chain ${ }^{9-11}$. Industrial wastes are major sources of pollution, therefore, on-site treatment is necessary before discharge into sewage system ${ }^{12}$.

However, these effluents ${ }^{18}$ are purposely used for irrigation due to scarcity of water especially for vegetables and fruits. Effluent for irrigation has been practiced for centuries throughout the world ${ }^{14,15}$. It provides farmers with a nutrient enriched water supply and society with a reliable and inexpensive system for wastewater treatment and disposal ${ }^{16}$. This is being done without knowing the effects of contaminants present in effluents on the growth and quality of different plants. Very little work is reported in the literature on the effect of soya waste on the growth of soybean. The present paper is a part of systematic work undertaken to study the effect of effluents on the growth of various plants and thereby to control the pollution load by studying the growth of soya bean plants in the soil blended with soya waste.

\section{Experimental}

Soya waste, an effluent from Rasoya Proteins Pvt. Limited, Wani Dist- Yavatmal (India) was collected in a clean container. The standard methods ${ }^{17}$ were used to measure $\mathrm{pH}$, electrical conductivity, $\mathrm{Ca}, \mathrm{Mg}, \mathrm{Na}, \mathrm{K}$, chlorides, sulphates, bicarbonates present in the water sample and soya waste. Seeds of soybean were collected from Market. Soil samples collected at $25 \mathrm{~cm}$ depth were air dried and powdered. Three different types of soil $\mathrm{S}_{1}, \mathrm{~S}_{2}$ and $\mathrm{S}_{3}$ were blended with soya waste in wt $\% 0,2,5,10,15,20 \%$ etc. and were kept in clean polythene bags. All plants were watered equally with same period and same water. All chemicals used were of GR/AR Grade.

The height, number of leaves and number of fruits of each plant were recorded after every month for three months. The observations were taken in rainy, winter and summer seasons.

\section{Results and Discussion}

Table 1 shows the results of physicochemical parameters of soya waste and water. The physicochemical characteristics of the soils $S_{1}, S_{2}$ and $S_{3}$ are shown in Table 2. Observations of growth of soybean plant with respect to plant height, number of leaves, flowers and fruits for three soils were recorded.

The experiment was started in rainy season and the optimum value for plant height was observed by blending for $S_{1}$ at $15 \%$ (22 inches) while for soil $S_{2}$, the optimum height was at $20 \%$ (22 inches) and for soil $S_{3}$ it was at $15 \%$ (20 inches). This may be due to high WHC and porosity of $S_{1}$ and $S_{2}$. The optimum values of plant leaves for $S_{1}$ were found at $15 \%$ (67 leaves), for $S_{2}$ at $20 \%$ (68) where as for $S_{3}$, the leaves were maximum at $15 \%$ blending (73 leaves). This variation might be due to high phosphorous content in $\mathrm{S}_{3}$ which aids in root development, flower initiation and seed and fruits development .The maximum flowering was observed at $15 \%$ (49) for $S_{1}$ while for $S_{2}$ at $20 \%$ (42) and for $S_{3}$ it was observed at $15 \%(43)$. Figure (1) shows number of fruits for $S_{1}, S 2$ and $S_{3}$ at various concentrations. The maximum fruits for $S_{1}$ were found at $10 \%$ (32) whereas for $S_{2}$ and $S_{3}$, the fruits were maximum at $20 \%$ (28) and $30 \%$ (31) respectively. Therefore, $15 \%$ and $10 \%$ for $\mathrm{S}_{1}, 20 \%$ for $\mathrm{S}_{2}$ and $15 \%$ and $30 \%$ blending concentration for $\mathrm{S}_{3}$ emerged as optimum level concentration 
for soybean plant. This might be due to the soya waste effluent being rich source sodium $(0.94 \mathrm{meq} / \mathrm{L})$, potassium $(0.47 \mathrm{meq} / \mathrm{L})$ and sulphates $(3.21 \mathrm{meq} / \mathrm{L})$ and other plant nutrients. The use of soya waste at these concentration resulted in reduced toxicity and better utilization of plant nutrients like Na, Cl, N, P \& K. Similar results were obtained by Sahai ${ }^{18}$ et al., in rice crop wherein they noticed that at $5 \%$ effluent concentration, the overall growth was better than in control whereas at higher concentration the growth was retarded.

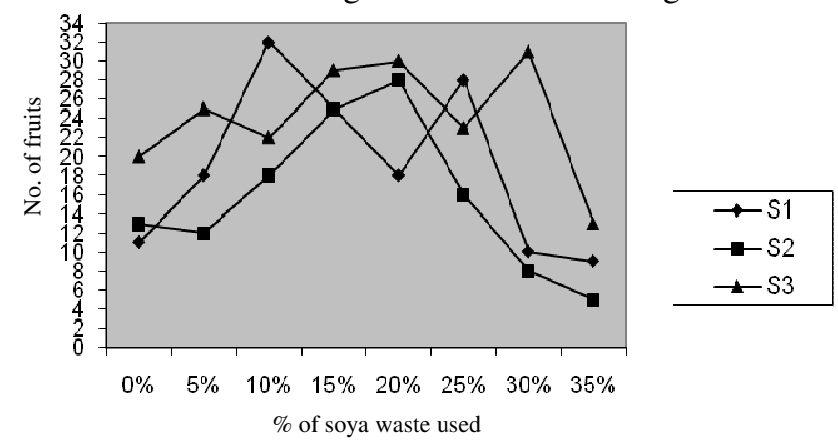

Figure 1. No. of fruits in Sep-2009

Table 1. Physicochemical characteristics of soya waste and water

\begin{tabular}{cccc}
\hline S No. & Parameters & Soya waste & Water \\
\hline 1 & pH & 7.66 & 7.18 \\
2 & Conductivity & $1.345 \mathrm{mS} / \mathrm{cm}$ & $3.41 \mathrm{mS} / \mathrm{cm}$ \\
3 & Calcium & $3.9 \mathrm{meq} / \mathrm{L}$ & $4.8 \mathrm{meq} / \mathrm{L}$ \\
4 & Magnesium & $1.8 \mathrm{meq} / \mathrm{L}$ & $1.6 \mathrm{meq} / \mathrm{L}$ \\
5 & Sodium & $0.94 \mathrm{meq} / \mathrm{L}$ & $0.71 \mathrm{meq} / \mathrm{L}$ \\
6 & Potassium & $0.47 \mathrm{meq} / \mathrm{L}$ & $0.41 \mathrm{meq} / \mathrm{L}$ \\
7 & Bicarbonates & $1.6 \mathrm{meq} / \mathrm{L}$ & $2.0 \mathrm{meq} / \mathrm{L}$ \\
8 & Chlorides & $1.6 \mathrm{meq} / \mathrm{L}$ & $2.0 \mathrm{meq} / \mathrm{L}$ \\
\hline
\end{tabular}

Table 2. Physicochemical characteristics of soils

\begin{tabular}{clccc}
\hline S. No. & \multicolumn{1}{c}{ Parameters } & $\mathrm{S}_{1}$ & $\mathrm{~S}_{2}$ & $\mathrm{~S}_{3}$ \\
\hline 1 & Bulk density g/cc & 1.49 & 1.61 & 1.78 \\
2 & W.H.C\% & 75.83 & 75.83 & 58.42 \\
3 & $\mathrm{pH}$ & 7.63 & 7.70 & 7.65 \\
4 & Conductivity, $\mathrm{mS} / \mathrm{cm}$ & 0.51 & 0.53 & 0.50 \\
5 & P as phosphate, kg/hectre & 16 & 18 & 20 \\
6 & Na\% & 0.52 & 1.78 & 0.63 \\
7 & K, kg/hectre & 552 & 625 & 289 \\
8 & Organic C \% & 0.39 & 0.34 & 0.49 \\
9 & Ca \% & 36 & 27 & 29.25 \\
10 & Mg\% & 3.68 & 9.20 & 3.68 \\
11 & Porosity \% & 60.05 & 54.52 & 35.63 \\
12 & Moisture \% & 8.99 & 7.16 & 10.02 \\
13 & Zn, ppm & 0.25 & 0.48 & 0.47 \\
14 & Cu, ppm & 1.16 & 2.84 & 1.41 \\
15 & Fe, ppm & 0.29 & 0.56 & 0.64 \\
16 & Mn, ppm & 2.04 & 5.21 & 1.62 \\
\hline
\end{tabular}


In winter, the optimum height for $S_{1}$ was at $20 \%$ (23 inches), for $S_{2}$ it was at $20 \%$ (15 inch) and for $S_{3}$ it was at $15 \%$ (16.5 inches). The maximum leaves were found for $S_{1}$ at $15 \%$ (75), for $S_{2}$ at $20 \%$ (69) and for $S_{3}$ at $15 \%$ (77). The flowering was maximum at $20 \%$ (36) for $S_{1}$, for $S_{2}$ it was also at $20 \%$ (38) and for $S_{3}$ at $10 \%$ (42). Figure 2 shows the number of fruits for soils $S_{1}, S_{2}$ and $S_{3}$ at different concentrations. For $S_{1}$ the maximum fruits were observed at $20 \%$ (24), for $S_{2}$ also the optimum value was at $20 \%$ (27) and for $S_{3}$ it was at $10 \%$ (28). Thus, in winter, $15 \%$ and $20 \%$ for soil $S_{1}, 10 \%$ and $20 \%$ for $S_{2}$ and for $S_{3}, 10 \%$ and $15 \%$ blending concentration are the optimum level concentration for soybean plant. The fairly good results for $\mathrm{S}_{3}$ may be attributed to the better \% of organic $\mathrm{C}, \mathrm{P}$ and $\mathrm{Fe}$ in $\mathrm{S}_{3}$. However, higher or lower concentrations of the effluent than these in respective soils decreased the growth parameters of soybean plant. These findings are in accordance with the observations recorded by Somashekar ${ }^{19}$ et al., in jowar, bajra and rice.

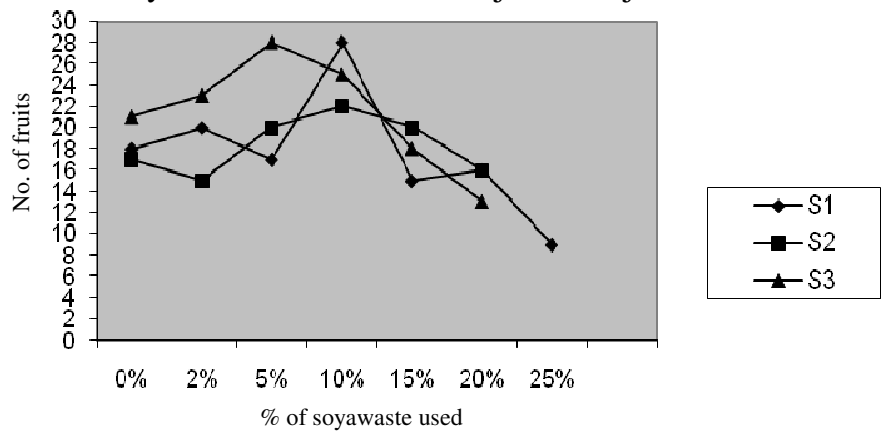

Figure 2. No. of fruits in March-2010

The optimum value for plant height in summer was found at $10 \%$ (19 inches) for $S_{1}$ and the optimum height for $S_{2}$ was also at $10 \%$ (19.5 inches). But for $S_{3}$, the maximum height was at 15 $\%$ (20 inches). The observations showed maximum leaves for $S_{1}$ at 5\% (82), for $S_{2}$ at $15 \%$ (70) and for $S_{3}$ at $10 \%$ (81) blending concentration. The flowering for all the three soil samples $S_{1}, S_{2}$ and $\mathrm{S}_{3}$ was found maximum at $10 \%$ blending concentration with 47,34 and 35 flowerings respectively. This shows that, the nutrients present in $10 \%$ soya waste-soil blending concentration and weathering conditions were supportive to the flowering growth of plants. The number of fruits for $S_{1}, S_{2}$ and $S_{3}$ were as shown in Figure 3. 10\% blending concentration for all the three soil samples $S_{1}, S_{2}$ and $S_{3}$ showed maximum fruits as 28,22 and 20 respectively. Thus, in summer, $5 \%$ and $10 \%$ for $S_{1}, 10 \%$ and $15 \%$ blending concentrations for $S_{2}$ and $S_{3}$ are the optimum level concentrations. The promotional influence on plant growth by these concentrations of effluents might be due to optimum level plant nutrients in the effluent.
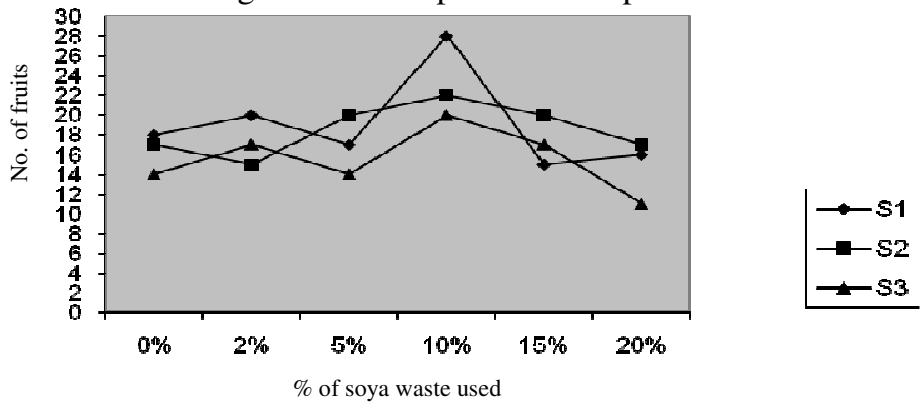

Figure 3. No. of fruits in July-2010 
From the commercial view point overall maximum number of fruits was found in rainy season for $10-30 \%$ blending, in winter season for 5-10\% blending and in summer for $10 \%$ blending. This indicates that, the ingredients present in the blends of soya waste and soil at particular concentration are supportive to the growth of plant.

Johnson ${ }^{20}$ et al., reported that plant growth on metallic ferrous mine soil is restricted by high concentration of toxic metals and by the low level of micro nutrients in the substrates. Results of field trials on calcareous and acidic soil showed that inert amendments may be more suitable for revegetation and for recreational purposes. Diluted spent wash increase the height, growth and yield of leaves vegetables ${ }^{21}$ due to increase in nutrient uptake, nutrient of top vegetable ${ }^{22}$, pulses, condiment and root vegetables also increased due to SP treatment.

Warhate $^{23}$ et al., studied the impact of continuous mining on water and soil of Wani region. The study indicated the adverse influence of mining activities on soil quality. Shrivastava $^{24}$ et al., studied the effect of effluent of paper mill industries on seed germination and early growth performance of Radish and Onion. He found that germination and early growth were decreased by chloro-alkali paper effluent. Islam ${ }^{25}$ et al., studied the impact of effluents on plant growth and soil properties and observed that the contaminated soil exerted significant negative effect on the growth, yield and nutrition of rice and grass plant grown in it and the reduction were more pronounced in rice. These negative effects may be ascribed to the excessive concentration of effluents.

\section{Conclusion}

From the results, $10-25 \%$ effluent-soil blending concentration showed positive results it means that ingredients present in soya waste are essential nutrients at particular concentration only and are supportive to the plant growth. Thus, utilization of soya waste in agriculture may save costs on fertilizer and facilitate the reduction in pollution load if used in proper ratio by blending.

\section{Acknowledgement}

One of the authors, P. B. Thakare is grateful to The Principal and the management of Arts, Commerce and Science College, Arvi, Tq. Arvi Dist., Wardha, M.S., India. Thanks are also due to The Principal and Head of Chemistry Department, Bapurao Deshmukh College of Engineering, Sevagram, Dist., Wardha, M.S., India, for providing all the laboratory facilities.

\section{References}

1. Arora B R, Azad A S, Singh B and Sekhon G S, Indian J Ecol., 1985, 12, 1-7.

2. Narwal R P, Antil R S and Gupta A P, J Soil Contamination, 1992, 1, 265-272.

3. Antil R S and Narwal R P, Problems and prospectus of utilization of sewer water in Haryana. In: Management of Organic Wastes for Crop Production, K.K.Kapoor, Sharma P K, Dudeja S S, Dudeja B S and Kundu B S, (Ed.), Department of Microbiology, CCS Haryana Agricultural University, Hisar, India, 2005, 159-168.

4. Gupta A P, Antil R S and Singh A, Proceedings of National Seminar On Environmental Pollution Control and Monitoring, 419-425, CSIO Chandigarh, India, October 22-26, 1986.

5. Gupta A P, Narwal R P, Antil R S, Singh A and Poonia S R, Impact of sewage water irrigation on soil health. In: Impact Of Modern Agriculture On Environment, Behl R K, Arora S K and Tauro P, (Ed)., CCS Haryana Agricultural University, Hisar and Max Muller Bhawan, New Delhi, 1994, 109-117,

6. Gupta A P, Narwal R P and Antil R S, Bioresour Technol., 1998, 65(1), 171-173. 
7. Narwal R P, Gupta A P, Singh A and Karwasra S P S, Annals Biol, 1993, 9, 239-245.

8. Bajwa $\mathrm{H}$, Water contamination causing DNA mutation, The Indian Express, Chandigarh Edition, India, 2008, 5.

9. Tu C, Zheng C R and Chen H M, Acta Pedol Sin (in Chinese), 2000, 37, 284-287.

10. Dahamani-Muller H, van Oort F and Balabane M, Environ Pollut., 2001, 114(1), 77-84.

11. Mcgrath S P, Zhao J and Lombi E, Advances Agronomy, 2002, 75, 1-56.

12. Emongor V, NKegebe E, Kealotswe B, Koorapetse I, Sankwasa S and Keikanetswe S, $J$ Appl Sci., 2005, 5(1), 147-150.

13. Ghafoor A, Rauf A, Arif M and Muzaffar W, Pak J Agri Sci., 1994, 31(4), 367-369.

14. Shuval H I, Adin A, Fattal B, Rawitz E and Yekutiel P, Wastewater irrigation in developing countries, Health effects and technical solutions, World Bank Technical Report, 1986, 51, 325.

15. Tripathi D M, Tripathi S and Tripathi B D, J Environ Prot., 2011, 2(5), 655-661.

16. Feigin A, Ravina I and Shalhevet J, Advanced Series in Agricultural Sciences, Springer-Verla, 1991, 17, 224.

17. APHA (American Public Health Association): Standard methods for the Examination of Water and Wastewater, Washington DC, Edn., 2005, 21.

18. Sahai R, Jabeen S and Saxena P K, Indian J Ecol., 1983, 10(1), 7-10.

19. Somashekar R K, Gowda M T G, Shettigar S L N and Srinath K P, Indian J Environ. Health, 1984, 26(2), 136-146.

20. Johnson M S, Mcnielly T and Putwain P D, J Environ Poll., 1997, 12, 261-277.

21. Chandraju S and Basavaraju H C, Sugar J (SISSTA), 2007, 5, 1-10.

22. Chandraju S, Siddapa and Chidan Kumar C S, Current Botany, 2011, 2(3), 38-42.

23. Warhate S R, Yenkie M K N, Choudhary M D and Pokale W K, J Environ Sci Eng., 2006, 48(2), 81-90.

24. Shrivastava R K, J Ecotoxicol Environ Monit., 1991, 1(1), 13-18.

25. Islam M O, Md Khan H R, Das A K, Akhtar M S, Oki Y and Adachi T, Soil Environ., 2006, 25(2), 113-118. 